\title{
Potential of Seaweed Extract on Growth, Physiological, Cytological and Biochemical Parameters of Wheat (Triticum aestivum L.) Seedlings
}

\author{
Marwa M. Hamouda ${ }^{1} \cdot$ Khalil M. Saad-Allah ${ }^{1}\left[\right.$ Dina Gad $^{2}$
}

Received: 1 November 2021 / Accepted: 11 January 2022 / Published online: 17 January 2022

(c) The Author(s) 2022

\begin{abstract}
Synthetic fertilizers are widely employed in agriculture relative to biofertilizers. Long-term use affects soil fertility, plant vigor, human and livestock health, and the soil microbial community. Seaweeds were employed as biofertilizers in sustainable agriculture to overcome this issue and boost the agricultural productivity. Therefore, the current study investigates the effect of wheat seeds priming with the aqueous extracts of Ulva linza or Corallina officinalis seaweeds at various concentrations $(5,10,15,20$, and $30 \%)$. Wheat grains were primed with seaweed extracts and grown in petri dishes, and the germination rate, growth attributes, physiological parameters, cytological traits, and molecular analyses were evaluated. The physico-chemical characterization revealed that $U$. linza possessed higher levels of ash, soluble proteins, and sugars, as well as essential macronutrients and amino acids, than $C$. officinalis. Seedling growth parameters, physiological characteristics, and mitotic index all showed a substantial increase in low concentrations of both extracts when compared to the control. Higher concentrations, on the other hand, exhibited an inhibitory effect as well as certain chromosomal abnormalities. In the treated seedlings, new proteins were expressed, which could be owing to the activity of bioactive components in the extracts. As compared to untreated seedlings, PCR-RAPD analysis utilizing five markers revealed that both seaweed extracts triggered low and high molecular weight DNA fragments, as well as fragments specific to each extract. Seaweed extracts could be employed as an environmentally friendly and soil-safe alternative to typical chemical fertilizers.
\end{abstract}

Keywords Bio-fertilizer $\cdot$ Triticum aestivum $\cdot$ Seaweed extract $\cdot$ Growth performance $\cdot$ Molecular analysis

\section{Introduction}

The use of conventional chemical fertilizers has risen substantially as a result of the world's rapidly growing population and ever-increasing food demand. The use of these chemical fertilizers and their effects, particularly on the environment, has become a major concern (Eissa et al. 2017). As a result, farmers began to switch to organic farming rather than using synthetic agricultural fertilizers. Seaweeds are abundant and sustainable resources found throughout coastlines worldwide and are considered primary producers of food, feed, biofuels, cosmetics,

Khalil M. Saad-Allah

khalil.saadallah@science.tanta.edu.eg

1 Botany Department, Faculty of Science, Tanta University, Tanta 31527, Egypt

2 Botany and Microbiology Department, Faculty of Science, Menoufia University, Shebin El-Koum, Egypt fertilizers, nutraceuticals, and pharmaceuticals (Bixler and Porse 2011). Due to their commercial value and prospective applications, seaweeds are employed as fodder, human food, cosmetics, biorefineries, and biofertilizers (PeñaRodríguez et al. 2011). Macroalgae extracts are currently being utilized as foliar sprays or presoaking for stimulating the growth and production of a range of plants, notably crops, due to the availability of several growth regulators, trace elements, vitamins, and amino acids (Abdel Khalik and Osman 2017). Annually, more than 15 million tons of seaweeds are produced, with a significant amount of that being used as biofertilizers in agricultural and horticultural sectors (Anisimov et al. 2013).

The use of seaweeds as plant bio-stimulants is now one of the most promising applications. This effect can be explained by the presence of plant growth-promoting molecules like indoleacetic acid (IAA), gibberellic acid (GA), abscisic acid (ABA), cytokinins, and polyamines, in algal extracts (Prasad et al. 2010). Also, other important 
phytochemicals were identified in seaweed extracts including phenols, betaines, lipids, proteins, sugar alcohols, alginates, and laminarins (Shukla et al. 2018). Such chemical compounds provide a variety of positive physiological reactions in a variety of crops, resulting in enhanced growth and production as well as stress tolerance (Hussain et al. 2021). In addition to delaying senescence, the biologically active phytochemicals in seaweed extracts promote root and shoot growth, chlorophyll content, and antioxidant activity (Battacharyya et al. 2015). Furthermore, seaweed extract was found to boost the activity of antioxidative and nitrogen metabolizing enzymes (such as glutamine synthetase) (Fan et al. 2013). Also, Jannin et al. (2013) reported that seaweed extracts significantly upregulated the genes involved in carbon fixation resulting in enhanced photosynthetic efficiency. Consequently, seaweeds have been recognized as a major source of macro- and micronutrients necessary for regular metabolism and proper plant growth. The mineral composition of Ulva linza revealed the presence of several nutrients such as $\mathrm{Na}^{+}, \mathrm{k}^{+}, \mathrm{Ca}^{2+}, \mathrm{Mg}^{2+}, \mathrm{Cl}^{-}$, and $\mathrm{NO}_{3}$, implying that this green seaweed might be explored for future use in medicine, nutritional supplements, cosmetics, or the food industry (Jiang et al. 2013).

Earlier studies revealed that seaweed extracts have a considerable impact on wheat development and yield components. Spraying wheat plants with seaweed extracts resulted in a significant increase in grain weight and yield/plant. These extracts had a stimulating effect because they were high in bioactive components like macro- and micronutrients, essential fatty acids, amino acids, vitamins, cytokinins, and auxins, which boosted cellular metabolism in treated plants, resulting in improved growth and productivity (Stirk et al. 2003; Chernane et al. 2015). Kasim et al. (2015) also found that employing Ulva seaweed extract reduced the oxidative damage caused by drought not only by activating the antioxidative system but also by providing essential hormones and minerals for wheat growth.

Wheat (Triticum aestivum L.) is a grass family (Poaceae) member that is grown for cereal grain in both spring and winter habit forms. In terms of production and consumption for human food and animal feed, it is among the most important grains on the planet. Every year, Egypt produces ten million tons of wheat and imports another ten million tons (Asseng et al. 2018). The core objective of stakeholders is to increase wheat production in order to close the massive gap between availability and demand (Ali et al. 2008). The objective of this study is to see how pre-sowing seed priming with different concentrations of the seaweed liquid fertilizers (SLFs) derived from the chlorophyte Ulva linz $a$ and the rhodophyte Corallina officinalis affect wheat germination, seedlings growth, physiological and molecular aspects.

\section{Material and methods}

\subsection{Collection of seaweeds}

The two seaweed species used in this study, Ulva linza Linnaeus and Corallina officinalis Linnaeus, were collected from the Eastern Harbour, Alexandria coast, Egypt, during October 2019. The collected samples were washed thoroughly with seawater to remove all the unwanted impurities, adhering sand particles, and epiphytes. The samples were placed separately in polythene bags, kept inside an ice box, and transported to the laboratory. Samples were thoroughly rinsed with tap water to remove surface salt, then distilled water and spread out on blotting paper to remove excess water. Samples were air-dried for 15 days at $35^{\circ} \mathrm{C}$ before being thermally dried for $12 \mathrm{~h}$ at $60^{\circ} \mathrm{C}$.

\subsection{Preparation of seaweed liquid extracts (SLEs)}

The oven-dried seaweeds were crushed by hand before being pulverized in a mixer-grinder. Seaweed powders were heated for $45 \mathrm{~min}$ at $60^{\circ} \mathrm{C}$ in sterile distilled water $(1: 100 \mathrm{w} / \mathrm{v})$, after which the extracts were filtered through filter paper and stored at $4{ }^{\circ} \mathrm{C}$ for further experimental studies. The filtrate was considered as $100 \%$, and different concentrations of SLEs were generated by diluting this extract with distilled water to concentrations of $5,10,15,20$, and $30 \%$.

\subsection{Physico-chemical characteristics of SLEs}

The $\mathrm{pH}$ of SLEs was assessed using a $\mathrm{pH}$ meter, and their color was observed visually. Soluble protein content was determined according to the method described by Bradford (1976). The lipid content was determined using Northcote et al. (1958) technique. Soluble carbohydrate fraction was measured according to Dubois et al. (1965). The individual free amino acids in SLEs were estimated by the method of Moore et al. (1958). Ash analysis and estimation of macronutrients $(\mathrm{N}, \mathrm{P}, \mathrm{Ca}, \mathrm{Mg}$, and $\mathrm{K})$ and micronutrients $(\mathrm{Na}, \mathrm{Fe}$, $\mathrm{Zn}, \mathrm{Cd}, \mathrm{Cu}$, and $\mathrm{Pb}$ ) in SLEs were performed according to the AOAC (1995) method.

\subsection{Treatments and experimental design}

Kernels of Triticum aestivum L., cv. Sakha 93 were supplied by the Agricultural Research Center, Giza, Egypt, and selected for apparent size and shape uniformity. The grains were surface-sterilized for 8 min with $5 \% \mathrm{NaOCl}$, rinsed multiple times with tap water, and then rinsed with distilled water. The sterilized grains were primed by soaking them for $12 \mathrm{~h}$ in various concentrations of $U$. linza 
or C. officinalis (SLFs) aqueous extracts $(5,10,15,20$, and $30 \%$ ), whereas control grains were primed in distilled water for the same period. To remove the excess solutions, the priming solutions were drained and the grains were spread out on a paper tissue. In 9-cm-diameter Petri dishes with a double layer of filter papers, 10 grains of each treatment were placed. Petri dishes were saturated with distilled water and grown in controlled conditions (12:12 day/ night, $23 / 14{ }^{\circ} \mathrm{C} \pm 2$, and $65 \%$ relative humidity). Each treatment included three replicates in a completely randomized design. On the fourth day following sowing, the germination rate was calculated and some cytological data (mitotic index and abnormality index) were recorded on the developing root tips. Seedlings were moistened as needed, and on the 15th day following sowing, seedlings were collected to assess growth criteria (length, fresh mass, and dry mass of both shoots and roots), as well as physiological and molecular examinations.

\subsection{Phytochemical analyses}

According to the procedures of Arnon (1949), total chlorophyll was quantified in fresh wheat leaves. The approach outlined by Kirk and Allen (1965) was employed to evaluate carotenoids. The total soluble protein content of wheat leaves was measured quantitatively using Bradford (1976) method based on BSA as a standard protein. The free proline content was determined using a calibration curve created using proline, as described by Bates et al. (1973). The concentration of soluble sugars in wheat leaves was quantified using the method outlined by Dubois et al. (1965). Total lipids were extracted from wheat leaves and assayed using the technique implemented by Northcote et al. (1958). Using a standard curve generated from atropine, the total alkaloid content was measured spectrophotometrically according to Shamsa et al. (2010).

\subsection{Cytological studies}

A parallel germination experiment on Petri plates was conducted until radicles acquired a length of $1-2 \mathrm{~cm}$ to explore the impact of seaweed extracts on cell division rate and chromosome morphology. Roots from each treatment were fixed in a mixture of absolute ethanol and glacial acetic acid $(3: 1 \mathrm{v} / \mathrm{v})$ for $24 \mathrm{~h}$ before being stored in $70 \%$ ethanol at $4{ }^{\circ} \mathrm{C}$ until usage. Roots were then hydrolyzed, stained, and squeezed before being inspected under a microscope $(100 \times)$, and mitotic index was calculated by analyzing at least 1500 cells and chromosomal abnormalities were recorded per SLF concentration.

\subsection{Protein pattern analysis via electrophoresis}

SDS-PAGE was used to identify protein electrophoretic patterns using the technique implemented by Laemmli (1970). Protein extracts from 15-day-old wheat seedlings were electrophoresed, stained, and photographed, and then the molecular weight of protein bands was determined using protein molecular weight marker of 10-200 kDa.

\subsection{PCR-RAPD analysis}

DNA was extracted from 15-day-old wheat seedlings using the JET ${ }^{\mathrm{TM}}$ Plant Genomic DNA Purification Kit according to the manufacturer's instructions. To amplify genomic DNA, five primers were utilized (Table 1). The RAPD-PCR procedures were performed as described in Sambrook and Russell (2001). The PCR reaction mixture $(25 \mu \mathrm{L})$ was made up of $1 \mu \mathrm{L}$ DNA, $1 \mu \mathrm{L} \mathrm{MgCl}_{2}, 2 \mu \mathrm{L}$ primer, $12.5 \mu \mathrm{L}$ Bio-Mix Red, and $8.5 \mu \mathrm{L}$ of nuclease-free water. PCR amplification program began with an initial denaturation at $94^{\circ} \mathrm{C}$ for $5 \mathrm{~min}$, 39 cycles of denaturation at $94{ }^{\circ} \mathrm{C}$ for $60 \mathrm{~s}$, primer annealing at $36^{\circ} \mathrm{C}$ for $45 \mathrm{~s}$, and $1 \mathrm{~min}$ extension at $72{ }^{\circ} \mathrm{C}$. The last extension was then performed at $72{ }^{\circ} \mathrm{C}$ for $10 \mathrm{~min}$ before cooling for $3 \mathrm{~min}$ at $4{ }^{\circ} \mathrm{C}$. Electrophoresis on a $1.2 \%$ agarose gel with ethidium bromide stain was used to examine the products of amplified DNA. Finally, photos of the gels were taken with a digital camera, and the presence or absence of bands was assigned a score of 1 or 0 , respectively. The molecular weights of the RAPD bands were estimated using Kapelan GmbH's Lab Image software version 2.7.

\subsection{Statistical analysis}

To assess the effect of both seaweed extracts and concentrations, as well as their interactions on the measured parameters, the acquired experimental findings were statistically analyzed using the two-way analysis of v(ANOVA). Oneway ANOVA was also performed to determine the degree of significance between various treatments and to separate the means. CoStat software was used to conduct the whole statistical analysis. The data presented as the average of three replicates \pm the standard deviation.

Table 1 Sequence of primers used in PCR-RAPD analysis $\left(5^{\prime} \rightarrow 3^{\prime}\right)$

\begin{tabular}{ll}
\hline Primer & Sequence \\
\hline OPG-03 & GAGCCCTCCA \\
OPP-01 & GTAGCACTCC \\
OPP-10 & TCCCGCCTAC \\
OPC-17 & TTCCCCCCAG \\
OPG-01 & CTACGGAGGA \\
\hline
\end{tabular}


Table 2 Physico-chemical characters of Ulva linza and Corallina officinalis seaweed extracts

\begin{tabular}{lll}
\hline Parameters & U. linza & C. officinalis \\
\hline Color & Green & Red \\
$\mathrm{pH}$ & $6.64 \pm 0.02$ & $6.70 \pm 0.05$ \\
Ash $(\%)$ & $36.15 \pm 0.81$ & $31.06 \pm 0.53$ \\
Protein (\%) & $5.36 \pm 0.07$ & $4.51 \pm 0.04$ \\
Lipid (\%) & $1.05 \pm 0.04$ & $1.28 \pm 0.05$ \\
Carbohydrate $\%)$ & $5.38 \pm 0.08$ & $4.61 \pm 0.05$ \\
$\mathrm{~N}\left(\mathrm{mg} \mathrm{L}^{-1}\right)$ & $249.0 \pm 10.21$ & $142.0 \pm 6.03$ \\
$\mathrm{P}\left(\mathrm{mg} \mathrm{L}^{-1}\right)$ & $8.30 \pm 0.35$ & $6.60 \pm 0.28$ \\
$\mathrm{Ca}\left(\mathrm{mg} \mathrm{L}^{-1}\right)$ & $0.38 \pm 0.01$ & $0.63 \pm 0.12$ \\
$\mathrm{Mg}\left(\mathrm{mg} \mathrm{L}^{-1}\right)$ & $0.48 \pm 0.03$ & $0.58 \pm 0.02$ \\
$\mathrm{~K}\left(\mathrm{mg} \mathrm{L}^{-1}\right)$ & $118.75 \pm 0.11$ & $112.35 \pm 0.86$ \\
$\mathrm{Na}\left(\mathrm{mg} \mathrm{L}^{-1}\right)$ & $47.49 \pm 0.44$ & $36.21 \pm 0.82$ \\
$\mathrm{Fe}\left(\mathrm{mg} \mathrm{L}^{-1}\right)$ & $3.86 \pm 1.38$ & $2.75 \pm 1.88$ \\
$\mathrm{Zn}\left(\mathrm{mg} \mathrm{L}^{-1}\right)$ & $0.56 \pm 0.01$ & $0.27 \pm 0.01$ \\
$\mathrm{Cd}\left(\mathrm{mg} \mathrm{L}^{-1}\right)$ & $0.026 \pm 0.00$ & $0.012 \pm 0.00$ \\
$\mathrm{Cu}\left(\mathrm{mg} \mathrm{L}^{-1}\right)$ & $0.56 \pm 0.02$ & $0.32 \pm 0.08$ \\
$\mathrm{~Pb}\left(\mathrm{mg} \mathrm{L}^{-1}\right)$ & $0.59 \pm 0.03$ & $0.39 \pm 0.01$ \\
\hline
\end{tabular}

\section{Results}

The results reported in Table 2 display the physico-chemical characteristics of SLFs from U. linza and C. officinalis. SLFs were green or red in color, with $\mathrm{pH}$ values of 6.62 and 6.67 for $U$. linza and $C$. officinalis, respectively. The ash content of $U$. linza was higher (36.15\%) than that of $C$. officinalis (31.06\%). U. linza had higher percentages of soluble proteins and carbohydrates (5.36 and $5.38 \%$, respectively) than $C$. officinalis (4.51 and $44.61 \%$, respectively). C. officinalis, on the other hand, had a slightly greater lipid content (1.28\%) than $U$. linza $(1.05 \%)$. Regarding the content of macronutrients in both algal species, $U$. linza possessed higher amounts of $\mathrm{N}, \mathrm{P}$, and $\mathrm{K}\left(249.0,8.3\right.$, and $118.7 \mathrm{mg} \mathrm{L}^{-1}$, respectively) compared to their counterparts in C. officinalis (142.0, 6.6, and $112.3 \mathrm{mg} \mathrm{L}^{-1}$, respectively). $\mathrm{Ca}$ and $\mathrm{Mg}$, on the other hand, revealed a reversal of trend, with 0.63 and $0.58 \mathrm{mg}$ $\mathrm{L}^{-1}$ in C. officinalis and 0.38 and $0.48 \mathrm{mg} \mathrm{L}^{-1}$ in $U$. linza, respectively. The amount of micronutrients represented in $\mathrm{Na}, \mathrm{Fe}, \mathrm{Zn}, \mathrm{Cd}, \mathrm{Cu}$, and $\mathrm{Pb}$ were higher in $U$. linza (47.49, $3.86,0.56,0.026,0.56$, and $0.59 \mathrm{mg} \mathrm{L}^{-1}$, respectively) than in C. officinalis (36.21, 2.75, 0.27, 0.012, 0.32, and $0.39 \mathrm{mg}$ $\mathrm{L}^{-1}$ respectively).

Amino acid analysis of $U$. linza and $C$. officinalis (Table 3) resulted in the detection of 13 amino acids with reasonably resolved separations. $C$. officinalis had a slightly greater total amino acid content $\left(84.39 \mathrm{mg} \mathrm{g}^{-1} \mathrm{DM}\right.$ (dry mass)) than $U$. linza (83.85 $\left.\mathrm{mg} \mathrm{g}^{-1} \mathrm{DM}\right)$. Six essential amino acids (histidine, threonine, methionine, leucine, lysine, and phenylalanine) were present in varying amounts
Table 3 Amino acids analysis of $U$. linza and C. officinalis $\left(\mathrm{mg} \mathrm{g}^{-1}\right.$ DM)

\begin{tabular}{lll}
\hline Amino acid & U. linza & C. officinalis \\
\hline Aspartic acid & $5.27 \pm 0.25$ & $10.21 \pm 0.59$ \\
Glutamic acid & $7.08 \pm 0.32$ & $15.47 \pm 1.02$ \\
Serine & $4.42 \pm 0.12$ & $7.24 \pm 0.64$ \\
Glycine & $5.19 \pm 0.20$ & $7.11 \pm 0.38$ \\
Histidine & $1.32 \pm 0.02$ & $1.46 \pm 0.03$ \\
Arginine & $3.88 \pm 0.18$ & $5.71 \pm 0.34$ \\
Threonine & $4.60 \pm 0.17$ & $5.84 \pm 0.18$ \\
Proline & $2.55 \pm 0.09$ & $2.29 \pm 0.08$ \\
Tyrosine & $1.26 \pm 0.02$ & $1.31 \pm 0.02$ \\
Methionine & $8.12 \pm 0.31$ & $2.41 \pm 0.10$ \\
Leucine & $5.52 \pm 0.33$ & $7.89 \pm 0.64$ \\
Lysine & $7.32 \pm 0.41$ & $2.22 \pm 0.06$ \\
Phenylalanine & $27.32 \pm 1.94$ & $15.23 \pm 1.06$ \\
Essential & 54.20 & 35.05 \\
Non-essential & 29.65 & 49.34 \\
Total amino acids & 83.85 & 84.39 \\
\hline
\end{tabular}

in the two seaweeds. The essential amino acids in $U$. linza (54.20 $\mathrm{mg} \mathrm{g}^{-1} \mathrm{DM}$ ) were higher than those of $C$. officinalis (35.05 $\left.\mathrm{mg} \mathrm{g}^{-1} \mathrm{DM}\right)$. Phenylalanine was the most abundant essential amino acid in both species' extracts (27.32 and $15.32 \mathrm{mg} \mathrm{g}^{-1} \mathrm{DM}$ in $U$. linza and $C$. officinalis, respectively). The order of essential amino acids in $U$. linza was phenylalanine ' methionine > lysine > leucine > threonine > histidine, but in $C$. officinalis their order was phenylalanine ' leucine > threonine ' methionine > lysine ' histidine. Thus, histidine was the least abundant essential amino acid in both seaweed species. Nonetheless, $C$. officinalis' non-essential amino acids (49.34 $\mathrm{mg} \mathrm{g}^{-1} \mathrm{DM}$ ) outperformed those of $U$. linza $\left(29.65 \mathrm{mg} \mathrm{g}^{-1} \mathrm{DM}\right)$. The most abundant non-essential amino acids of $C$. officinalis and $U$. linza were glutamic (15.47 and $7.08 \mathrm{mg} \mathrm{g}^{-1} \mathrm{DM}$, respectively) and aspartic acid (10.21 and $5.27 \mathrm{mg} \mathrm{g}^{-1} \mathrm{DM}$, respectively). However, the least dominant non-essential amino acids were tyrosine followed by histidine in both seaweed species.

The influence of $U$. linza and $C$. officinalis extracts on wheat germination percentage and growth parameters are reported in Fig. 1. The data showed that increasing SLF concentrations up to $20 \%$ boosted germination rate (1a), total plant length (1b), total fresh mass (1c), and total dry mass (1d) of wheat seedlings, but the highest concentration (30\%) declined it, as compared to the control treatment. In comparison to the control, $U$. linza $20 \%$ extract effectively increased germination rate, total plant length, total fresh mass, and total dry mass of wheat seedlings by 18.07, 33.04, 55.35, and $75.82 \%$, respectively. In the case of C. officinalis, a $20 \%$ extract increased germination rate by $17.23 \%$, but a $15 \%$ concentration increased total plant length, total fresh mass, and 
Fig. 1 Effect of seed priming with different concentrations of $U$. linza and $C$. officinalis seaweed extracts on a germination percentage, b plant length, $\mathbf{c}$ fresh mass, and $\mathbf{d}$ dry mass of wheat seedlings. Results are means of 3 replicates \pm SD. Different letters denote significant differences at 0.05 level in the same species treatments
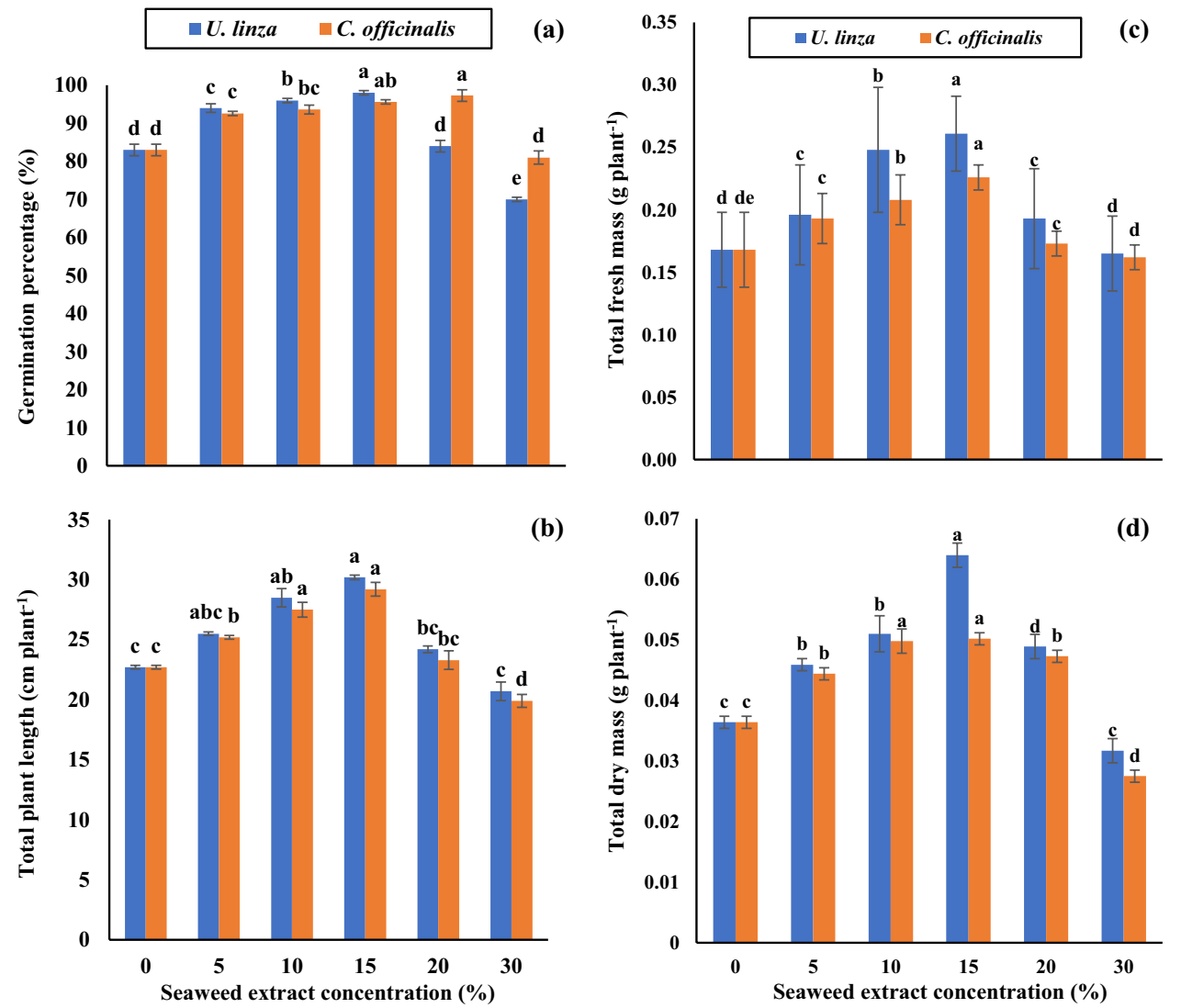

total dry mass by $28.63,34.52$, and $37.91 \%$, respectively, as compared to the control. As a result, the extract of $U$. linza was more efficacious than the extract of $C$. officinalis in promoting wheat germination and growth rates.

The physiological parameters of 15-day-old wheat seedlings primed with two seaweed extracts are reported in Table 4. The chlorophyll content of wheat leaves was affectedly increased by $U$. linza and $C$. officinalis seaweed extracts in a concentration-dependent manner. While the $15 \%$ concentration of the two seaweed extracts provoked the maximum chlorophyll content $\left(20.3\right.$ and $18.1 \mathrm{mg} \mathrm{g}^{-1}$ FM (fresh mass), respectively), higher concentrations nonsignificantly lowered chlorophyll content as compared to the control. Carotenoids in wheat leaves followed the same trend, with 4.0 and $3.8 \mathrm{mg} \mathrm{g}^{-1} \mathrm{FM}$ in the case of $U$. linza and C. officinalis, respectively, attributable to $15 \%$ concentration seaweed extract. In comparison to the control value, higher seaweed extracts had a non-significant increase in carotenoids. Herein, a $15 \%$ concentration of the two seaweeds was found to be the most effective in enhancing photosynthetic pigments in wheat leaves with the superiority of $U$. linza extract over that of $C$. officinalis.

Seed priming with $U$. linza and $C$. officinalis seaweed extracts had a substantial impact on the primary metabolites (sugars, proteins, and lipids) of wheat seedlings (Table 4). When compared to the control, the extract of $U$. linza increased all of the primary metabolites. The increment was proportional to the extract concentration up to $15 \%$, which produced the highest levels of sugars, proteins, and lipids (35.5, 16.3, and $7.1 \mathrm{mg} \mathrm{g}^{-1} \mathrm{DM}$, respectively) when compared to other treatments, but the trend slowed at higher concentrations. Similarly, $C$. officinalis extract induced an increase in primary metabolites, with a concentration of $15 \%$ stimulatory effect over other concentrations. Similarly, when compared to other doses, the stimulatory effect of $15 \% \mathrm{C}$. officinalis extract on primary metabolites was greater. This concentration yielded the largest levels of sugars, proteins, and lipids (32.0, 15.3, and $6.8 \mathrm{mg} \mathrm{g}^{-1} \mathrm{DM}$, respectively) in wheat seedlings. In general, $U$. linza stimulated the accumulation of primary metabolites in wheat seedlings more than $C$. officinalis.

Priming with SLFs had a significant impact on proline and alkaloid accumulation in wheat seedlings (Table 4). Priming with $U$. linza extract resulted in reduced concentrations of proline and alkaloids in wheat leaves, with a sequential drop until $15 \%$ concentration, which produced the least proline and alkaloids (18.2 and $6.16 \mathrm{mg} \mathrm{g}^{-1} \mathrm{DM}$, respectively) compared to control levels. Higher concentrations, on the other hand, increased proline and alkaloid accumulation. The reduction in proline concentration with C. officinalis extract was sustained up to $15 \%$ concentration, after which it increased again to achieve the maximum level 
Table 4 Effect of seed priming with different concentrations of $U$. linza and $C$. officinalis seaweed extracts on the physiological parameter (chlorophyll, carotenoids, sugars, proteins, lipids, proline, and alkaloids) of wheat seedlings. Results are mean of 3 replicates \pm SD. Different letters in the same column denote significant differences at 0.05 level

\begin{tabular}{|c|c|c|c|c|c|c|c|c|}
\hline Seaweed species & $\begin{array}{l}\text { Conc } \\
(\%)\end{array}$ & $\begin{array}{l}\text { Chlorophyll } \\
\left(\mathrm{mg} \mathrm{g}^{-1} \mathrm{FM}\right)\end{array}$ & $\begin{array}{l}\text { Carotenoids } \\
\left(\mathrm{mg} \mathrm{g}^{-1} \mathrm{FM}\right)\end{array}$ & $\begin{array}{l}\text { Sugars } \\
\left(\mathrm{mg} \mathrm{g}^{-1} \mathrm{DM}\right)\end{array}$ & $\begin{array}{l}\text { Proteins } \\
\left(\mathrm{mg} \mathrm{g}^{-1} \mathrm{DM}\right)\end{array}$ & $\begin{array}{l}\text { Lipids } \\
\left(\mathrm{mg} \mathrm{g}^{-1} \mathrm{DM}\right)\end{array}$ & $\begin{array}{l}\text { Proline } \\
\left(\mathrm{mg} \mathrm{g}^{-1} \mathrm{DM}\right)\end{array}$ & $\begin{array}{l}\text { Alkaloids } \\
\left(\mathrm{mg} \mathrm{g}^{-1} \mathrm{DM}\right)\end{array}$ \\
\hline \multirow[t]{6}{*}{ U. linza } & 0 & $11.8 \pm 0.20 \mathrm{f}, \mathrm{c}$ & $2.5 \pm 0.21 \mathrm{~d}$ & $14.4 \pm 1.51 \mathrm{~d}, \mathrm{f}$ & $10.5 \pm 0.35 \mathrm{e}, \mathrm{d}$ & $3.7 \pm 0.13 \mathrm{~d}, \mathrm{e}$ & $26.1 \pm 2.13 \mathrm{a}, \mathrm{d}$ & $12.0 \pm 0.47 \mathrm{a}, \mathrm{d}$ \\
\hline & 5 & $15.4 \pm 0.40 \mathrm{~d}$ & $2.7 \pm 0.15 \mathrm{~cd}$ & $22.1 \pm 1.24 \mathrm{c}$ & $12.5 \pm 0.19 \mathrm{c}$ & $6.1 \pm 0.31 \mathrm{c}$ & $23.2 \pm 1.63 b$ & $10.1 \pm 0.81 b$ \\
\hline & 10 & $14.4 \pm 0.42 \mathrm{e}$ & $2.8 \pm 0.11 \mathrm{c}$ & $21.1 \pm 2.51 \mathrm{c}$ & $11.3 \pm 0.90 \mathrm{~d}$ & $6.0 \pm 0.26 \mathrm{c}$ & $22.1 \pm 1.74 c$ & $8.1 \pm 0.35 d$ \\
\hline & 15 & $17.2 \pm 0.25 b$ & $3.4 \pm 0.31 b$ & $31.3 \pm 2.05 b$ & $14.4 \pm 0.26 b$ & $6.5 \pm 0.43 b$ & $20.1 \pm 0.95 d$ & $8.7 \pm 0.71 \mathrm{c}$ \\
\hline & 20 & $16.3 \pm 0.10 \mathrm{c}$ & $3.3 \pm 0.16 b$ & $30.1 \pm 3.01 b$ & $12.5 \pm 0.43 c$ & $6.2 \pm 0.56 \mathrm{c}$ & $19.0 \pm 1.03 \mathrm{e}$ & $7.3 \pm 0.31 \mathrm{e}$ \\
\hline & 30 & $20.3 \pm 0.76 a$ & $4.0 \pm 0.29 \mathrm{a}$ & $35.5 \pm 2.15 \mathrm{a}$ & $16.3 \pm 0.62 \mathrm{a}$ & $7.1 \pm 0.27 \mathrm{a}$ & $18.2 \pm 1.70 \mathrm{f}$ & $6.2 \pm 0.27 f$ \\
\hline \multirow[t]{5}{*}{ C. officinalis } & 5 & $18.1 \pm 0.20 \mathrm{a}$ & $3.8 \pm 0.14 \mathrm{a}$ & $32.0 \pm 2.59 \mathrm{a}$ & $15.3 \pm 0.54 \mathrm{a}$ & $6.8 \pm 0.48 \mathrm{a}$ & $16.1 \pm 0.81 \mathrm{e}$ & $6.8 \pm 0.36 f$ \\
\hline & 10 & $12.3 \pm 0.25 b$ & $3.4 \pm 0.16 b$ & $22.5 \pm 1.62 b$ & $11.2 \pm 0.34 \mathrm{c}$ & $5.4 \pm 0.63 b$ & $28.2 \pm 1.57 \mathrm{bc}$ & $13.0 \pm 0.19 \mathrm{c}$ \\
\hline & 15 & $11.3 \pm 0.10 \mathrm{~d}$ & $3.2 \pm 0.24 b$ & $21.0 \pm 2.07 \mathrm{c}$ & $13.2 \pm 0.46 b$ & $5.2 \pm 0.19 \mathrm{~d}$ & $27.1 \pm 1.08 \mathrm{~cd}$ & $10.1 \pm 0.24 \mathrm{e}$ \\
\hline & 20 & $11.7 \pm 0.29 \mathrm{c}$ & $2.9 \pm 0.19 \mathrm{c}$ & $19.9 \pm 0.79 \mathrm{~d}$ & $11.0 \pm 0.95 \mathrm{~cd}$ & $4.8 \pm 0.30 \mathrm{c}$ & $30.2 \pm 2.63 \mathrm{a}$ & $15.1 \pm 0.37 \mathrm{a}$ \\
\hline & 30 & $10.9 \pm 0.15 \mathrm{e}$ & $2.7 \pm 0.21 \mathrm{~cd}$ & $18.1 \pm 1.51 \mathrm{e}$ & $10.8 \pm 0.07 \mathrm{~cd}$ & $4.2 \pm 0.25 \mathrm{~d}$ & $29.0 \pm 2.71 \mathrm{ab}$ & $14.1 \pm 0.40 \mathrm{~b}$ \\
\hline \multicolumn{9}{|l|}{ Significance } \\
\hline Seaweed extract (SE) & & $* * *$ & ns & $* * *$ & $* * *$ & $* * *$ & $* * *$ & $* * *$ \\
\hline Concentration (C) & & $* * *$ & $* * *$ & $* * *$ & $* * *$ & $* * *$ & $* * *$ & $* * *$ \\
\hline SE x C & & $* * *$ & $* * *$ & $* * *$ & $* * *$ & $* * *$ & $* * *$ & $* * *$ \\
\hline
\end{tabular}

ns $=$ non-significant $* * *=P<0.001$

(29.0 $\mathrm{mg} \mathrm{g}^{-1} \mathrm{DM}$ ) at $30 \%$ concentration. Also, alkaloids were steadily reduced in wheat seedlings following priming with $C$. officinalis extract to a concentration of $20 \%$, but the higher extract concentration increased alkaloid accumulation in wheat seedlings when compared to the control.

Seed priming with the extracts from two seaweeds, $U$. linza and $C$. officinalis, significantly affected the mitotic index and chromosomal abnormalities in the root cells of wheat seedlings (Table 5). The increase in the mitotic index was proportional to the concentration of seaweed extracts up to $15 \%$; this concentration resulted in the maximum index (34.0 and 35.3\%, in the case of $U$. linza and $C$. officinalis, respectively), after which the rate of increment decreased as the concentration of seaweed extracts increased. In the case of the control treatment or seaweed extracts up to $15 \%$ concentration, no chromosomal abnormalities were identified. However, at 20 and $30 \%$ concentrations, several chromosomal abnormalities were detected in the dividing cells. The highest concentration (30\%) of $U$. linza extract induced $7.5 \%$ chromosomal abnormalities in wheat root cells, whereas this treatment resulted in $8.6 \%$ abnormalities in the case of $C$. officinalis extract (Fig. 2). Chromosomal bridge with lagging chromosome (2a), chromatin bridge (2b), micronuclei (2c), multipolar cell with chromosomal bridge $(2 \mathrm{~d})$, multinucleated cell (2e), and chromosomal stickiness (2f) were among the abnormalities detected.

After seed priming with various concentrations (5-30\%) of $U$. linza and $C$. officinalis seaweed extracts, total proteins extracted from the leaves of wheat seedling were analyzed using SDS-PAGE (Fig. 3). Under all study treatments, 33 bands with molecular weights ranging from 10 to $223 \mathrm{kDa}$ were identified, 20 of which were monomorphic and 13 of which were polymorphic. The experimental treatment affected the number and intensity of protein bands. Monomorphic bands (present in all treatments) have a range of molecular sizes, from low to high molecular weight proteins, i.e., $12,18,20,21,23,30,40,43,46,49,57,62,68,79$, $88,94,107,119,148$, and $223 \mathrm{kDa}$. In comparison to the control and higher concentrations, the low concentrations (5-15\%) of both seaweed extracts induced the appearance of three peptides with low molecular weight $(16,28$, and $53 \mathrm{kDa}$ ) and two peptides with high molecular weight (170 and $184 \mathrm{kDa})$. However, following seed priming with high concentrations (20 and 30\%) of both seaweed extracts, five low molecular weight distinct bands with molecular sizes of $10,14,24,25$, and $26 \mathrm{kDa}$ appeared in wheat seedlings. At various concentrations, each seaweed extract displayed a distinct band: a band with a molecular weight of $73 \mathrm{kDa}$ for $U$. linza and a band with a molecular weight of $133 \mathrm{kDa}$ for C. officinalis. Both seaweed extracts triggered the production of a novel peptide with a molecular weight of $83 \mathrm{kDa}$ at all doses tested.

The expression of particular genes is linked to the phenology and physiology of wheat seedlings primed with two seaweed extracts, which contribute to the plant's improved growth and development. Table 6 summarizes the results of RAPD-PCR analysis of wheat seedlings treated with different concentrations of $U$. linza and $C$. officinalis seaweed extracts. Five primers, OPG-03, OPP-01, OPP-10, OPC-17, and OPG-01, were examined in this investigation 






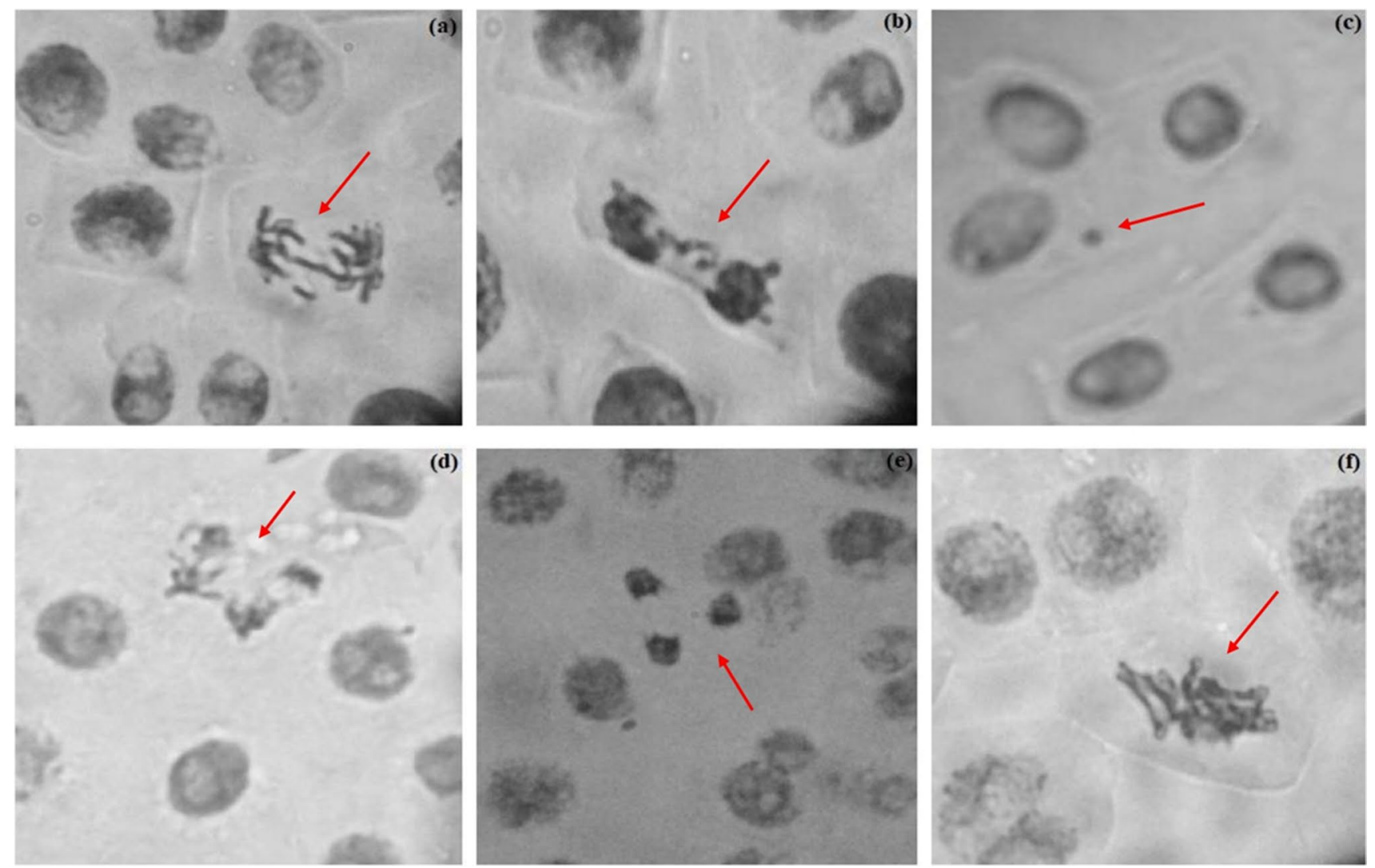

Fig. 2 Types of chromosomal abnormalities in the root meristems of wheat following seed priming with different concentrations of seaweed extract. Abnormal cell: a chromosome bridge with lagging chromosome, $\mathbf{b}$ chromatin bridge, $\mathbf{c}$ micronuclei, $\mathbf{d}$ multipolar with bridge, e multinucleated cell, $\mathbf{f}$ stickiness
Fig. 3 Effect of different

concentration of $U$. linza and

C. officinalis seaweed extracts on the protein profile of wheat seedlings. $\mathrm{kDa}=$ kilo Dalton; $\mathrm{M}=$ Marker protein; $\mathrm{C}=$ control treatment

\section{$\underline{U}$. linza extract concentrations (\%) C. officinalis extract concentrations (\%)}

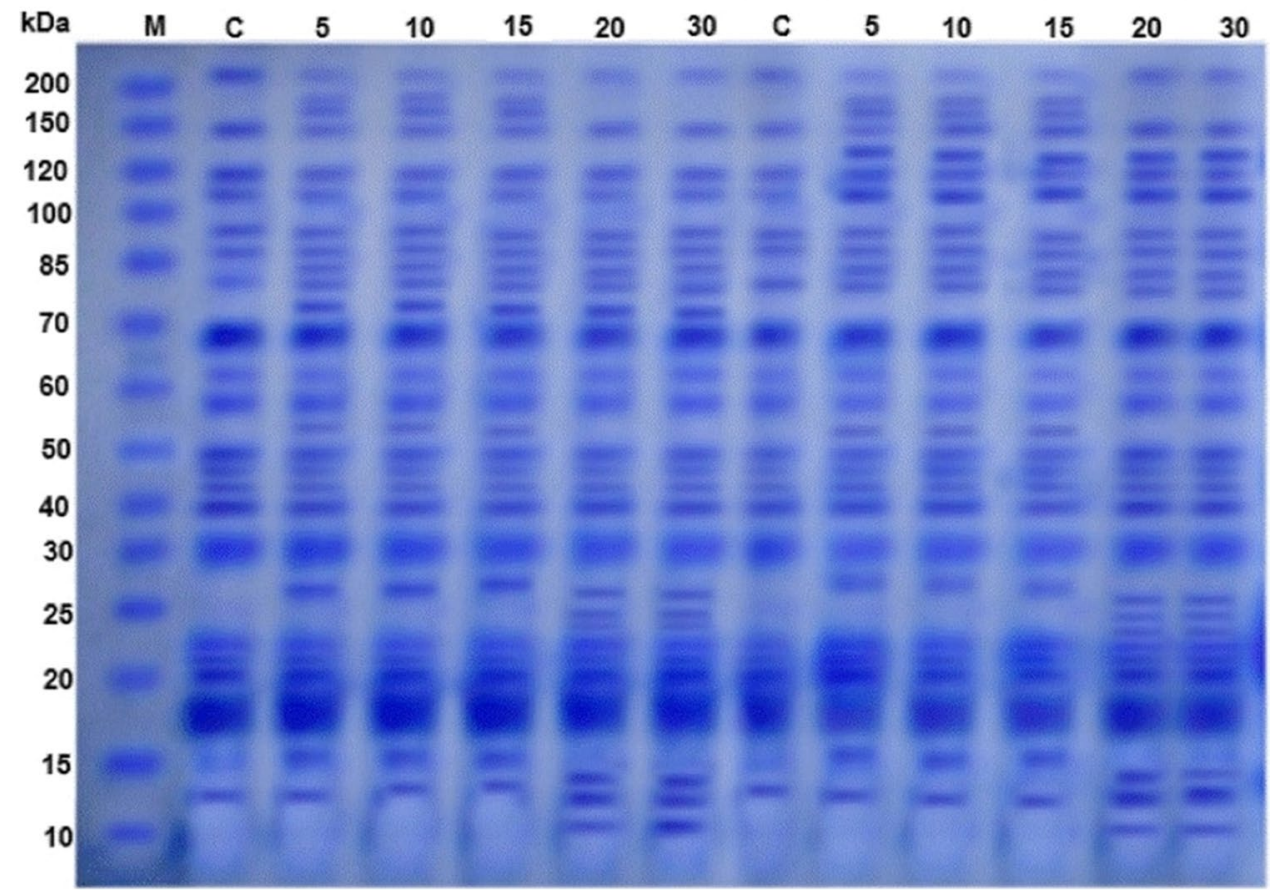


Table 6 RAPD-PCR profile produced by five primers (OPG-03, OPP-01, OPP-10, OPC-17, and OPG-01) showing the effect of seed priming with different concentrations of $U$. linza and $C$. officinalis extracts on the DNA patterns of wheat seedlings

\begin{tabular}{|c|c|c|c|c|c|c|c|c|c|c|c|c|}
\hline \multirow[t]{2}{*}{$\begin{array}{l}\text { Mo.wt } \\
\text { (bP) }\end{array}$} & \multirow[t]{2}{*}{ Ctrl } & \multicolumn{5}{|c|}{ U. linza extracts concentration (\%) } & \multicolumn{5}{|c|}{$\begin{array}{l}\text { C. officinalis extracts concentration } \\
(\%)\end{array}$} & \multirow[t]{2}{*}{$\begin{array}{l}\text { Band } \\
\text { type }\end{array}$} \\
\hline & & 5 & 10 & 15 & 20 & 30 & 5 & 10 & 15 & 20 & 30 & \\
\hline \multicolumn{13}{|c|}{ Primer OPG-03 } \\
\hline 1100 & 0 & 1 & 1 & 1 & 1 & 1 & 0 & 0 & 0 & 0 & 0 & $\mathrm{P}$ \\
\hline 1015 & 0 & 1 & 1 & 1 & 1 & 1 & 1 & 1 & 1 & 1 & 1 & $\mathrm{P}$ \\
\hline 923 & 0 & 1 & 1 & 1 & 1 & 1 & 1 & 1 & 1 & 1 & 1 & $\mathrm{P}$ \\
\hline 832 & 0 & 1 & 1 & 1 & 1 & 1 & 0 & 0 & 0 & 0 & 0 & $\mathrm{P}$ \\
\hline 757 & 0 & 0 & 0 & 0 & 1 & 1 & 0 & 0 & 0 & 1 & 1 & $\mathrm{P}$ \\
\hline 712 & 0 & 0 & 0 & 0 & 1 & 1 & 0 & 0 & 0 & 1 & 1 & $\mathrm{P}$ \\
\hline 613 & 0 & 1 & 1 & 1 & 1 & 1 & 1 & 1 & 1 & 1 & 1 & $\mathrm{P}$ \\
\hline 495 & 1 & 1 & 1 & 1 & 1 & 1 & 1 & 1 & 1 & 1 & 1 & M \\
\hline 427 & 1 & 1 & 1 & 1 & 1 & 1 & 1 & 1 & 1 & 1 & 1 & M \\
\hline 316 & 1 & 1 & 1 & 1 & 1 & 1 & 1 & 1 & 1 & 1 & 1 & M \\
\hline \multicolumn{13}{|c|}{ Primer OPP-01 } \\
\hline 1071 & 0 & 0 & 0 & 0 & 0 & 0 & 1 & 1 & 1 & 1 & 1 & $\mathrm{P}$ \\
\hline 815 & 0 & 1 & 1 & 1 & 1 & 1 & 1 & 1 & 1 & 1 & 1 & $\mathrm{P}$ \\
\hline 751 & 0 & 1 & 1 & 1 & 1 & 1 & 1 & 1 & 1 & 1 & 1 & $\mathrm{P}$ \\
\hline 653 & 0 & 0 & 0 & 0 & 1 & 1 & 0 & 0 & 0 & 1 & 1 & $\mathrm{P}$ \\
\hline 581 & 1 & 1 & 1 & 1 & 1 & 1 & 1 & 1 & 1 & 1 & 1 & M \\
\hline 405 & 1 & 1 & 1 & 1 & 1 & 1 & 1 & 1 & 1 & 1 & 1 & M \\
\hline 265 & 1 & 1 & 1 & 1 & 1 & 1 & 1 & 1 & 1 & 1 & 1 & M \\
\hline \multicolumn{13}{|c|}{ Primer OPP-10 } \\
\hline 729 & 0 & 1 & 1 & 1 & 1 & 1 & 1 & 1 & 1 & 1 & 1 & $\mathrm{P}$ \\
\hline 604 & 0 & 1 & 1 & 1 & 1 & 1 & 1 & 1 & 1 & 1 & 1 & $\mathrm{P}$ \\
\hline 491 & 0 & 1 & 1 & 1 & 1 & 1 & 1 & 1 & 1 & 1 & 1 & $\mathrm{P}$ \\
\hline 400 & 1 & 1 & 1 & 1 & 1 & 1 & 1 & 1 & 1 & 1 & 1 & M \\
\hline \multicolumn{13}{|c|}{ Primer OPC-17 } \\
\hline 958 & 0 & 0 & 0 & 0 & 1 & 1 & 0 & 0 & 0 & 1 & 1 & $\mathrm{P}$ \\
\hline 885 & 0 & 0 & 0 & 0 & 1 & 1 & 0 & 0 & 0 & 1 & 1 & $\mathrm{P}$ \\
\hline 832 & 0 & 1 & 1 & 1 & 1 & 1 & 1 & 1 & 1 & 1 & 1 & $\mathrm{P}$ \\
\hline 704 & 0 & 1 & 1 & 1 & 1 & 1 & 1 & 1 & 1 & 1 & 1 & $\mathrm{P}$ \\
\hline 61 & 0 & 1 & 1 & 1 & 1 & 1 & 1 & 1 & 1 & 1 & 1 & $\mathrm{P}$ \\
\hline 441 & 1 & 1 & 1 & 1 & 1 & 1 & 1 & 1 & 1 & 1 & 1 & M \\
\hline 368 & 1 & 1 & 1 & 1 & 1 & 1 & 1 & 1 & 1 & 1 & 1 & M \\
\hline \multicolumn{13}{|c|}{ Primer OPG-01 } \\
\hline 872 & 0 & 1 & 1 & 1 & 1 & 1 & 1 & 1 & 1 & 1 & 1 & $\mathrm{P}$ \\
\hline 88 & 0 & 0 & 0 & 0 & 0 & 0 & 1 & 1 & 1 & 1 & 1 & $\mathrm{P}$ \\
\hline 718 & 0 & 1 & 1 & 1 & 1 & 1 & 1 & 1 & 1 & 1 & 1 & $\mathrm{P}$ \\
\hline 605 & 0 & 1 & 1 & 1 & 1 & 1 & 0 & 0 & 0 & 0 & 0 & $\mathrm{P}$ \\
\hline 530 & 0 & 1 & 1 & 1 & 1 & 1 & 1 & 1 & 1 & 1 & 1 & $\mathrm{P}$ \\
\hline 237 & 1 & 1 & 1 & 1 & 1 & 1 & 1 & 1 & 1 & 1 & 1 & $\mathrm{M}$ \\
\hline
\end{tabular}

Mo.wt marker molecular weight; $b p$ base pair; $C t r l$ control; $M$ monomorphic; $P$ polymorphic to determine which one best reflects the effect of varying concentrations of seaweed extracts on wheat seedlings. The amplified products obtained by the RAPD profiles utilizing all samples ranged from $1100 \mathrm{bp}$ for primer OPG-03 to $237 \mathrm{bp}$ for primer OPG- 01 . With the 5 primers, a total of 34 bands were reported in wheat seedlings, 10 of which were monomorphic and 24 were polymorphic. Primer OPG-03 produced the most well-defined bands (10), whereas primer OPP-10 produced the least (4 bands). The data revealed vast variations in the size and number of bands between seedlings primed with various concentrations of seaweed extracts and the control seedlings. In response to the two seaweed extracts at all concentrations, bands with molecular sizes of 1015,923 , and $613 \mathrm{bp}$ have appeared, but the band of 
832 bp was specific for $U$. linza at all concentrations in the case of OPG-3 primer. Higher concentrations of seaweed extracts (20 and $30 \%$ ) resulted in the development of two bands with molecular sizes of 757 and $712 \mathrm{bp}$. In the case of primer OPP-01, all extracts of both seaweeds elicited two bands with molecular sizes of 815 and $751 \mathrm{bp}$. In addition, higher doses (20 and 30\%) of seaweed extracts resulted in the appearance of a band with a molecular size of $653 \mathrm{bp}$. C. officinalis extracts provoked the appearance of a specific band of $1071 \mathrm{bp}$. Nonetheless, the presence of a specific band of 1071 bp was elicited by $C$. officinalis extracts.

In the case of OPP-10 primer, seaweed extracts exerted a considerable impact on the expression of specific DNA fragments. The presence of three bands with molecular sizes of 729,604 , and $431 \mathrm{bp}$, which were absolutely lacking in the control seedlings, was promoted by these extracts. Furthermore, all seaweed extracts promoted the synthesis of three DNA fragments with molecular sizes of 832, 704, and $613 \mathrm{bp}$, but the bands of 958 and $885 \mathrm{bp}$ were distinct to the higher concentrations (20 and 30\%) of both seaweeds in the case of OPC-17 primer. The use of OPG-01 primer revealed that seaweed extracts from both species induced the synthesis of three DNA fragments with molecular sizes of 872,718 , and $530 \mathrm{bp}$; however, C. officinalis extracts stimulated the appearance of $88 \mathrm{bp}$ fragment and $U$. linza extracts stimulated the appearance of $605 \mathrm{bp}$ fragment.

\section{Discussion}

The findings of this study established that seed priming with Ulva linza or Corallina officinalis seaweeds could be employed as bio-fertilizers supporting wheat growth. Seed priming allows seeds to function better in both normal and stressful situations. Seed priming boosts pre-germination metabolic activities, boosts antioxidant system activity, and speeds up membrane mending (Masondo et al. 2018). Phytohormones, amino acids, polyamines, polyphenols, carbohydrates, alginates, amino acids, essential macro- and micronutrients, betaines, and vitamins are among the physiologically active compounds found in seaweed extracts that stimulate plant growth and development (Mahmoud et al. 2019). Priming wheat seeds with low concentrations of seaweed extracts resulted in high percentages of germination and seedling growth, whereas morphological measurements were suppressed at higher concentrations of the seaweed extracts. These findings might be due to the presence of growthpromoting substances such as indole-3-acetic acid, indole butyric acid, gibberellins, cytokinins, micronutrients $(\mathrm{Fe}$, $\mathrm{Cu}, \mathrm{Co}, \mathrm{Zn}, \mathrm{Mn}, \mathrm{Mo}$, and $\mathrm{Ni}$ ), vitamins, and amino acids (Shahbazi et al. 2015). Our findings are consistent with the earlier research on radish (Kasim et al. 2016), wheat (Mohy El-Din 2015), and maize (Al-Shakankery et al. 2014). The uptake of $\mathrm{Mg}, \mathrm{K}, \mathrm{N}$, and $\mathrm{Fe}$ from the seaweed extracts of $U$. linza and $C$. officinalis could explain the rise in growth criteria of wheat seedlings as a result of seed priming with low concentrations of SLFs (Yusuf et al. 2012). The concentration of nutrients, as well as the quantity of photosynthetic products produced by the plant, had an impact on seedling biomass. The use of seaweed extracts is thought to be capable of enhancing nutrient concentrations in the plant leaves by integrating growth hormones in the absorption and movement of these nutrients in the plant, as well as increasing the level of other growth activating compounds, resulting in an increase in plant biomass (Gupta et al. 2021). Nonetheless, the inhibitory effect of increased seaweed concentrations on wheat growth is consistent with the findings of Finnie and van Staden (1985), who attributed this effect to the high cytokinin concentration in these extracts.

Priming wheat seeds with the extracts of $U$. linza or $C$. officinalis promoted almost physiological parameters like chlorophyll, carotenoids, sugars, proteins, and lipids, with the exception of higher concentrations of $C$. officinalis with chlorophyll, as compared to the corresponding controls. These results could be explained by the fact that seaweed extracts with high magnesium and mineral content tended to increase leaf total chlorophyll and carotenoids concentration (Mohy El-Din 2015). As a result, the capacity and efficiency of the photosynthetic process, as well as nutrient availability and absorption, have improved, resulting in enhanced carbohydrate production (Fan et al. 2013; Kulkarni et al. 2019). The increased protein and sugar contents due to seaweed priming could be attributed to absorption of majority of the major elements in these extracts, particularly magnesium, which could have activated chlorophyll synthesis and, as a result, improved photosynthetic rates (Castellanos-Barriga et al. 2017). Higher de novo protein synthesis and lower protein oxidation are the sources of increased protein content in seaweed-treated plants, according to Abd-Elmoniem and Abd-Allah (2008), and may be due to its effect in increasing the uptake of nitrogen to the plant that is a precursor of amino acids. The increased lipid accumulation in seaweedtreated seedlings in this study might be due to the extracts' higher stabilizing effect on membrane lipids and increased activity of lipid-synthesizing enzymes, as well as decreased ROS generation, which causes lipid peroxidation and disrupts enzyme activity (Kasim et al. 2016).

The decrease in proline concentration in wheat seedlings caused by $U$. linza extract priming was linked to the increase in total soluble proteins, which could indicate that proline was integrated into protein synthesis. These findings show that the plants primed with seaweed extracts were subjected to less stress than the control plants, resulting in healthy growth. The results of the current study are consistent with those of Almaroai and Eissa (2020) and Campobenedetto et al. (2021). The fact that most of the plant's energy is 
directed to the biosynthetic route of macromolecules like carbohydrates and proteins may explain the lower proline accumulation in wheat seedlings. Another explanation for proline reduction following priming with seaweed extracts could be the existence of a connection between the chlorophyll and proline biosynthesis pathways, resulting in competition for glutamate as a common precursor for the two molecules (Tahri et al. 1997). The increased proline concentration in wheat seedlings after $C$. officinalis priming, on the other hand, was consistent with the findings of De Saeger et al. (2020), who explained this as a result of activation of proline synthesizing genes and reduced expression of proline degrading genes after seaweed priming.

Except for 20 and $30 \%$ C. officinalis, all concentrations of both seaweed extracts decreased alkaloid accumulation in wheat seedlings. To cope with environmental stress, plants have developed metabolic adaptability. In addition to their protective activities against biotic and abiotic stress, alkaloids serve as nitrogen reservoirs (Bhambhani et al. 2021). According to Kasim et al. (2016), the decrease in alkaloids as a result of seaweed priming could be ascribed to the seaweeds' potent antioxidant capacity, which protects the plant from the detrimental effects of ROS generated during cellular metabolism. Also, alkaloids as a nitrogen reservoir may be diverted into other metabolic pathways to make structural nitrogenous compounds, such as proteins and amino acids, because plants can dispense the protective role of alkaloids in this situation. High concentrations of seaweed extracts had negative effects on both morphological and physiological parameters of wheat seedlings in some cases, which could be due to the toxicity of seaweed extracts in high concentrations as a result of increased micronutrients like $\mathrm{Zn}$, $\mathrm{Cd}, \mathrm{Cu}$, and $\mathrm{Pb}$, that reduce metabolic activity and aggravate morphological and physiological parameters (Papenfus et al. 2013).

The mitotic index of wheat root cells increased gradually up to $15 \%$ concentration of both seaweed extracts, then fell again at higher concentrations. Seaweed extracts have been shown to contain a variety of bioactive compounds including vitamins, proteins, antioxidants, unsaturated fatty acids, and carotenoids, among several others, that stimulate root growth and mineral uptake besides inducing cell division and cell enlargement, resulting in increased overall plant growth (Aziz et al. 2011). Higher concentrations of seaweed liquid fertilizer slowed the mitotic index rate, which could be owing to high levels of minerals like $\mathrm{Fe}, \mathrm{Zn}, \mathrm{Cd}, \mathrm{Cu}$, and $\mathrm{Mn}$. These minerals impact some enzymatic activities and promptly depolarize the root cell membrane, increasing membrane permeability and inhibiting plant nutrient uptake, resulting in a reduction in cell division and inability to give all of the nutrients required by a plant in sufficient concentrations (El-sheekh et al. 2016; Kocira et al. 2019). Wheat root cells treated with higher concentrations of seaweed extracts of $U$. linza and $C$. officinalis showed certain chromosomal abnormalities. According to Jesus et al. (2016), both algal species possess high levels of phenols and alkaloids, which promote an overproduction of ROS, causing cell damage and DNA breakage. Higher concentrations of seaweed extracts can cause chromosomal abnormalities by disrupting DNA and protein synthesis, as well as preventing RNA translation and chromosome re-establishment (Qian 2004).

The electrophoretic profile of wheat seedling proteins revealed that seed priming with seaweed extracts resulted in the appearance of additional protein bands: three with low molecular weight (Mo.wt) and two with high Mo.wt. The existence of these proteins can be linked to the fact that seaweed extracts, as biostimulants, are a rich source of growth-promoting substance, lipids, amino acids, and minerals that trigger the expression of specific genes while also modifying critical gene products and induced proteins (Kasim et al. 2016). Also, by influencing the production of transcription factors and cell-type-specific genes, Johri and Mitra (2001) proposed that seaweed-based hormones play a crucial role in cell expansion, cell proliferation, and cell differentiation. Low molecular weight proteins elicited by seaweed extract priming could be prompted by hormones found in these extracts, and such proteins could represent phytohormone receptors, according to the study of AbdelLatif et al. (2018). Additionally, the high mineral content of these extracts, which has a significant role in controlling the production of several enzymes in addition to its vital role as a signaling molecule, could explain the induction of novel polypeptides by seeds priming in the algal extract (SaadAllah and Nessim 2016).

RAPD-PCR of wheat seedlings revealed the induction of new bands with a molecular size of $654 \mathrm{bp}$ using OPP01 primer, 858 and 885 bp using OPC-17 primer, and 757 and 712 bp using OPG-03 primer, all of which were linked with higher concentrations of $U$. linza and $C$. officinalis. This could be owing to the large level of phenol, which has antioxidant characteristics at greater concentrations. These antioxidants can damage important biomolecules, and nucleotide sequence alterations could occur (Al-Zubaidy and Al-Hamzawi 2020). Heavy metals found in higher concentrations of seaweed extracts may have an adverse effect on cell physiological processes and biomolecules such as membrane lipids, proteins, enzymes, and nucleic acids, as well as triggering oxidative damage directly or indirectly by stimulating ROS generation leading to DNA fragmentation (Mahmoud et al. 2019). The existence or absence of the different bands in specific locations could be attributed to alterations in nitrogen base sequences that make up the DNA strand, as well as changes in the metabolic activities linked with nucleic acids in plants (Kunert et al. 2003). Because the number of DNA-binding sites relies on the type of genome that corresponds to the utilized seaweed and the extent to 
which the enzyme is specified to those sites, the RAPD-PCR profile revealed that each seaweed extract produced distinct bands in wheat seedlings in this investigation (Mahmoud et al. 2019). As a result, numerous factors such as primer structure and the number of annealing sites in the genome determine the number of bands amplified by different primers (Tahir 2014).

\section{Conclusion}

The current study is a significant step toward promoting wheat growth using extracts from the seaweeds $U$. linz $a$ and C. officinalis. Because they include macronutrients such as $\mathrm{N}, \mathrm{P}, \mathrm{K}, \mathrm{Ca}, \mathrm{Mg}$, and some trace elements, as well as growth regulators, amino acids, and antioxidants, seaweeds are excellent natural fertilizers. According to the current study, using low concentrations of seaweed extract as a priming treatment improves plant growth, physiological features, and molecular traits, as well as having a considerably greater capacity to boost bioavailable macro- and micronutrients to the plant. Nonetheless, $U$. linza seaweed extract surpassed $C$. officinalis on wheat seedlings throughout all morphological, physiological, and molecular parameters. As a result, this research encourages breeders to utilize seaweed extracts as a partial replacement for chemical fertilizers in order to boost wheat germination, growth, and productivity. However, in order to expand their use as soil conditioners and growth stimulants, more research on the exact mechanism of seaweeds' growth-promoting action on field crops is needed in the future.

Author Contribution Marwa Hamouda: Conceptualization, visualization, methodology, validation, data curation, investigation, writingreviewing and editing.

Khalil M. Saad-Allah: Conceptualization, visualization, methodology, validation, data curation, software, investigation, writing (original draft preparation), writing — reviewing and editing.

Dina Gad: Conceptualization, Visualization, Methodology, Validation, Data curation, Investigation, Writing- Reviewing and Editing.

Funding Open access funding provided by The Science, Technology \& Innovation Funding Authority (STDF) in cooperation with The Egyptian Knowledge Bank (EKB).

\section{Declarations}

Conflict of Interest The authors declare no competing interests.

Open Access This article is licensed under a Creative Commons Attribution 4.0 International License, which permits use, sharing, adaptation, distribution and reproduction in any medium or format, as long as you give appropriate credit to the original author(s) and the source, provide a link to the Creative Commons licence, and indicate if changes were made. The images or other third party material in this article are included in the article's Creative Commons licence, unless indicated otherwise in a credit line to the material. If material is not included in the article's Creative Commons licence and your intended use is not permitted by statutory regulation or exceeds the permitted use, you will need to obtain permission directly from the copyright holder. To view a copy of this licence, visit http://creativecommons.org/licenses/by/4.0/.

\section{References}

Abdel Khalik K, Osman G (2017) Genetic analysis of Plectranthus L. (Lamiaceae) in Saudi Arabia based on RAPD and ISSR markers. Pak J Bot 49:1073-1084

Abdel-Latif A, Badr R, Osman G (2018) Potential of Ulva lactuca extract on growth, biochemical constituents, and activity of pepcarboxylase of Zea mays seedlings. Pak J Bot 50:1971-1978

Abd-Elmoniem EA, Abd-Allah AS (2008) Effect of green alga cells extract as foliar spray on vegetative growth, yield and berries quality of superior grapevines. Am J Agric Environ Sci 4:427-433

Ali S, Khan AR, Mairaj G, Arif M, Fida M, Bibi S (2008) Assessment of different crop nutrient management practices for yield improvement. Aust J Crop Sci 2:150-157

Almaroai YA, Eissa MA (2020) Role of marine algae extracts in water stress resistance of onion under semiarid conditions. J Soil Sci Plant Nutr 20:1092-1101. https://doi.org/10.1007/ s42729-020-00195-0

Al-Shakankery FM, Hamouda RA, Ammar MM (2014) The promotive effect of different concentrations of marine algae as biofertilizers on growth and yield of maize (Zea mays L.) plants. J Chem Biol Phys Sci 4:43201-43211

Al-Zubaidy IA, Al-Hamzawi MA (2020) DNA molecular characterization of sweet pepper cv. Flavio as affected by seaweed extract and amino acids. In: IOP Conference Series: Earth and Environmental Science. p 012040. https://doi.org/10.1088/1755-1315/553/1/ 012040

Anisimov M, Chaikina E, Klykov A, Rasskazov V (2013) Effect of seaweeds extracts on the growth of seedling roots of buckwheat (Fagopyrum esculentum Moench) is depended on the season of algae collection. Agric Sci Dev 2:67-75

AOAC (1995) Official methods of analysis, 16th edn. Association of Official Analytical Chemists, Washington

Arnon DI (1949) Copper enzymes in isolated chloroplasts. Polyphenoloxidase in Beta vulgaris. Plant Physiol 24:1-15. https://doi. org/10.1104/pp.24.1.1

Asseng S, Kheir AMS, Kassie BT, Hoogenboom G, Abdelaal AI, Haman DZ, Ruane AC (2018) Can Egypt become self-sufficient in wheat? Environ Res Lett 13:094012. https://doi.org/10.1088/ 1748-9326/aada50

Aziz NG, Mahgoub MH, Siam HS (2011) Growth, flowering and chemical constituents performence of Amaranthus tricolor plants as influenced by seaweed (Ascophyllum nodosum) extract application under salt stress conditions. J Appl Sci Res 7:1472-1484

Bates LS, Waldren RP, Teare ID (1973) Rapid determination of free proline for water-stress studies. Plant Soil 39:205-207. https://doi. org/10.1007/BF00018060

Battacharyya D, Babgohari MZ, Rathor P, Prithiviraj B (2015) Seaweed extracts as biostimulants in horticulture. Sci Hortic 196:3948. https://doi.org/10.1016/j.scienta.2015.09.012

Bhambhani S, Kondhare KR, Giri AP (2021) Diversity in chemical structures and biological properties of plant alkaloids. Molecules 26:3374. https://doi.org/10.3390/molecules26113374 
Bixler HJ, Porse H (2011) A decade of change in the seaweed hydrocolloids industry. J Appl Phycol 23:321-335. https://doi.org/10. 1007/s10811-010-9529-3

Bradford MM (1976) A rapid and sensitive method for the quantitation of microgram quantities of protein utilizing the principle of protein-dye binding. Anal Biochem 72:248-254. https://doi.org/ 10.1016/0003-2697(76)90527-3

Campobenedetto C, Agliassa C, Mannino G, Vigliante I, Contartese V, Secchi F, Bertea CM (2021) A biostimulant based on seaweed (Ascophyllum nodosum and Laminaria digitata) and yeast extracts mitigates water stress effects on tomato (Solanum lycopersicum L.). Agriculture 11:557-572. https://doi.org/10.3390/agricultur e11060557

Castellanos-Barriga LG, Santacruz-Ruvalcaba F, Hernández-Carmona G, Ramírez-Briones E, Hernández-Herrera RM (2017) Effect of seaweed liquid extracts from Ulva lactuca on seedling growth of mung bean (Vigna radiata). J Appl Phycol 29:2479-2488. https:// doi.org/10.1007/s10811-017-1082-x

Chernane H, Latique S, Mansori M, Kaoua ME (2015) Salt stress tolerance and antioxidative mechanisms in wheat plants (Triticum durum L.) by seaweed extracts application. IOSR J Agric Vet Sci Ver I 8:2319-2372. https://doi.org/10.9790/2380-08313644

De Saeger J, Van Praet S, Han T, Depuydt S (2020) Toward the molecular understanding of the action mechanism of Ascophyllum nodosum extracts on plants. J Appl Phycol 32:573-597. https://doi.org/ 10.1007/s10811-019-01903-9

Dubois M, Gilles K, Hamilton J, Rebers PA, Smith F (1965) Colorimetric method for determination of sugars and related substances. Anal Chem 28:350-356. https://doi.org/10.1021/ac60111a017

Eissa HF, Hassanien SE, Ramadan AM, El-Shamy MM, Saleh OM, Shokry AM, Abdelsattar M, Morsy YB, El-Maghraby MA, Alameldin HF, Hassan SM, OsmanGH MHT, Gad El-Karim GA, Madkour MA, Bahieldin A (2017) Developing transgenic wheat to encounter rusts and powdery mildew by overexpressing barley chi26 gene for fungal resistance. Plant Methods 13:1-13. https:// doi.org/10.1186/s13007-017-0191-5

El-Sheekh M, Ismail M, Hamouda M (2016) Influence of some brown seaweed extracts on germination and cytological responses of Trigonella foenum-graecum L. Biotechnol Indian J Res 12:1-12

Fan D, Hodges DM, Critchley AT, Prithiviraj B (2013) A commercial extract of brown macroalga (Ascophyllum nodosum) affects yield and the nutritional quality of spinach in vitro. Commun Soil Sci Plant Anal 44:1873-1884. https://doi.org/10.1080/00103624. 2013.790404

Finnie JF, van Staden J (1985) Effect of seaweed concentrate and applied hormones on in vitro cultured tomato roots. J Plant Physiol 120:215-222. https://doi.org/10.1016/S0176-1617(85)80108-5

Gupta S, Stirk WA, Plačková L, Kulkarni MG, Doležal K, Van Staden J (2021) Interactive effects of plant growth-promoting rhizobacteria and a seaweed extract on the growth and physiology of Allium cepa L. (onion). J Plant Physiol 262:153437. https://doi.org/10. 1016/j.jplph.2021.153437

Hussain HI, Kasinadhuni N, Arioli T (2021) The effect of seaweed extract on tomato plant growth, productivity and soil. J Appl Phycol 33:1305-1314. https://doi.org/10.1007/s10811-021-02387-2

Jannin L, Arkoun M, Etienne P, Laîné P, Goux D, Garnica M, Fuentes M, San Francisco S, Baigorri R, Cruz F, Houdusse F, Garcia-Mina J, Yvin J, Ourry A (2013) Brassica napus growth is promoted by Ascophyllum nodosum (L.) Le Jol. seaweed extract: microarray analysis and physiological characterization of $\mathrm{N}, \mathrm{C}$, and $\mathrm{S}$ metabolisms. J Plant Growth Regul 32:31-52. https://doi.org/10. 1007/s00344-012-9273-9

Jesus AA, Lima SF, Vendruscolo EP, Alvarez R, Contardi LM (2016) Agroeconomic analysis of sweet corn grown with biostimulant applied on seed. Rev La Fac Agron 115:119-127. 7 (https://www. cabdirect.org/cabdirect/FullTextPDF/2017/20173303899.pdf)
Jiang HP, Gao BB, Li WH, Zhu M, Zheng CF, Zheng QS, Wang CH (2013) Physiological and biochemical responses of Ulva prolifera and Ulva linza to cadmium stress. Sci World J 2013:1-11. https:// doi.org/10.1155/2013/289537

Johri M, Mitra D (2001) Action of plant hormones. Curr Sci 80:199_ 205 (https://www.jstor.org/stable/24104279)

Kasim WA, Hamada EAM, Shams El-Din NG, Eskander S (2015) Influence of seaweed extracts on the growth, some metabolic activities and yield of wheat grown under drought stress. Int $\mathbf{J}$ Agron Agric Res 7:173-189

Kasim WA, Saad-Allah K, Hamouda M (2016) Seed priming with extracts of two seaweeds alleviates the physiological and molecular impacts of salinity stress on radish (Raphanus sativus). Int $\mathrm{J}$ Agric Biol 18:653-660. https://doi.org/10.17957/JJAB/15.0152

Kirk JTO, Allen RL (1965) Dependence of chloroplast pigment synthesis on protein synthesis: Effect of actidione. Biochem Biophys Res Commun 21:523-530. https://doi.org/10.1016/0006-291X(65) 90516-4

Kocira S, Szparaga A, Kuboń M, Czerwińska E, Piskier T (2019) Morphological and biochemical responses of Glycine max (L.) Merr. To the use of seaweed extract. Agronomy 9:93. https://doi.org/10. 3390/agronomy 9020093

Kulkarni MG, Rengasamy KRR, Pendota SC, Gruz J, Plačková L, Novák O, Doležal K, Van Staden J (2019) Bioactive molecules derived from smoke and seaweed Ecklonia maxima showing phytohormone-like activity in Spinacia oleracea L. N Biotechnol 48:83-89. https://doi.org/10.1016/j.nbt.2018.08.004

Kunert KJ, Baaziz M, Cullis CA (2003) Techniques for determination of true-to-type date palm (Phoenix dactylifera L.) plants: a literature review. Emirates J Food Agric 15:1-16. https://doi.org/ 10.9755/ejfa.v14i1.5277

Laemmli UK (1970) Cleavage of structural proteins during the assembly of the head of bacteriophage T4. Nature 227:680-685. https:// doi.org/10.1038/227680a0

Mahmoud SH, Salama DM, El-Tanahy AMM, Abd El-Samad EH (2019) Utilization of seaweed (Sargassum vulgare) extract to enhance growth, yield and nutritional quality of red radish plants. Ann Agric Sci 64:167-175. https://doi.org/10.1016/j.aoas.2019. 11.002

Masondo NA, Kulkarni MG, Finnie JF, Van Staden J (2018) Influence of biostimulants-seed-priming on Ceratotheca triloba germination and seedling growth under low temperatures, low osmotic potential and salinity stress. Ecotoxicol Environ Saf 147:43-48. https://doi.org/10.1016/j.ecoenv.2017.08.017

Mohy El-Din SM (2015) Utilization of seaweed extracts as bio-fertilizers to stimulate the growth of wheat seedlings. Egypt J Expermintal Biol 11:31-39

Moore S, Spackman DH, Stein WH (1958) Automatic recording apparatus for use in the chromatography of amino acids. In: Federation proceedings. pp 1107-1115

Northcote DH, Goulding KJ, Horne RW (1958) The chemical composition and structure of the cell wall of Chlorella pyrenoidosa. Biochem J 70:391-397. https://doi.org/10.1042/bj0700391

Papenfus HB, Kulkarni MG, Stirk WA, Finnie JF, Van Staden J (2013) Effect of a commercial seaweed extract (Kelpak $®)$ and polyamines on nutrient-deprived (N, P and K) okra seedlings. Sci Hortic 151:142-146. https://doi.org/10.1016/j.scienta.2012.12.022

Peña-Rodríguez A, Mawhinney TP, Ricque-Marie D, Cruz-Suárez LE (2011) Chemical composition of cultivated seaweed Ulva clathrata (Roth) C. Agardh. Food Chem 129:491-498. https://doi.org/ 10.1016/j.foodchem.2011.04.104

Prasad K, Das AK, Oza MD, Brahmbhatt H, Siddhanta AK, Meena R, Eswaran K, Rajyaguru M, Ghosh PK (2010) Detection and quantification of some plant growth regulators in a seaweedbased foliar spray employing a mass spectrometric technique sans 
chromatographic separation. J Agric Food Chem 58:4594-4601. https://doi.org/10.1021/jf904500e

Qian XW (2004) Mutagenic effects of chromium trioxide on root tip cells of Vicia faba. J Zhejiang Univ Sci 5:1570-1576. https://doi. org/10.1631/jzus.2004.1570

Saad-Allah KM, Nessim AA (2016) Protective role of the seaweed Halimeda opuntia extract on cadmium-stressed Eruca sativa (Mill.). Egypt J Bot 56:863-881. https://doi.org/10.21608/ejbo.2016.3779

Sambrook J, Russell D (2001) Molecular cloning: a laboratory manual, 3rd edn. Cold Spring Harbor Laboratory Press, New York

Shahbazi F, Nejad MS, Salimi A, Gilani A (2015) Effect of seaweed extracts on the growth and biochemical constituents of wheat. Int J Agric Crop Sci 8:283-287. https://doi.org/10.1016/j.biortech. 2005.06.016

Shamsa F, Monsef H, Ghamooshi R, Verdian-rizi M (2010) Spectrophotometric determination of total alkaloids in some Iranian medicinal plants. J Appl Hortic 12:69-70

Shukla PS, Shotton K, Norman E, Neily W, Critchley AT, Prithiviraj B (2018) Seaweed extract improve drought tolerance of soybean by regulating stress-response genes. AoB Plants 10:1-8. https:// doi.org/10.1093/aobpla/plx051
Stirk WA, Novák O, Strnad M, Van Staden J (2003) Cytokinins in macroalgae. Plant Growth Regul 41:13-24. https://doi.org/10. 1023/A:1027376507197

Tahir NA (2014) Genetic variability evaluation among Iraqi rice (Oryza sativa $\mathrm{L}$ ) varieties using RAPD markers and protein profiling. Jordan J Biol Sci 7:13-18. https://doi.org/10.12816/0008207

Tahri E, Belabed A, Sadki K (1997) Effect of osmotic stress on the accumulation of proline, chlorophyll and mRNA coding for glutamine synthetase in three varieties of durum wheat (Triticum durum Desf.). Bull Sci Inst Rebat 21:81-89

Yusuf R, Kristiansen P, Warwick N (2012) Potential effect of plant growth regulators in two seaweed products. Acta Hortic 958:133138. https://doi.org/10.17660/ActaHortic.2012.958.15

Publisher's Note Springer Nature remains neutral with regard to jurisdictional claims in published maps and institutional affiliations. 